\title{
Some Major Persisting Problems in Soviet Agriculture
}

Professor Nove's panoramic review of Soviet agricultural developments since 1953 covers all points that should be included in a survey of this kind. His claim that the overall picture is not controversial is on the whole correct, though individual observers are likely to differ in assessing the importance of particular aspects or policies. Before I outline my views, brief comment is in order on two points.

Thus, I do not agree with the statement that there was no sharp increase in the volume of grain procurements between the early and the late Khrushchev years. Such an impression is conveyed by annual averages for 1953-58 and 1959-64. But we should keep in mind that the early years included two bumper crops (1956 and 1958), while the later period included only one such crop (1964), which was offset to a large extent by the nearly disastrous harvest of 1963. If all these years are excluded from the comparison, typical average procurements in the early years come to about 36 million tons, while the corresponding figure for 1959-62 is 51 million tons. This is an increase in the general level of procurements of about 41 percent. $^{1}$

I would also stress that the matter of the MTS reform is best viewed in the general context of other policy measures introduced at about the same time. These included changes in agriculture's terms of trade (to its disadvantage), a cutback in the production and supply of many important types of farm machinery, a slowdown in the rate of extending credits to agriculture, a low rate of increase in the production and shipments of mineral fertilizers, as well as the campaign against the private plot. I have discussed these matters at greater length elsewhere, ${ }^{2}$ and I still hold the view that all these measures taken together represented a major policy decision, made at the highest level, to reduce the supply of inputs to agriculture and to arrest (at least) the growth of agricultural incomes at a time when a very substantial increase in farm output was planned for 1959-65. The fact that this decision was taken after a period of very satisfactory growth in output in 1953-58 underlines the propen-

1. Tsentral'noe statisticheskoe upravlenie pri Sovete Ministrov SSSR, Narodnoe khoziaistvo SSSR v $1968 \mathrm{~g}$. (Moscow, 1969), p. 349.

2. J. F. Karcz, "Seven Years on the Farm: Retrospect and Prospect," in U.S. Congress, Joint Economic Committee, New Directions in the Soriet Economy, part 2-B (Washington, D.C., 1966), pp. 402-10. 
sity of Soviet leadership to rely excessively on the famous "internal reserves" of the agricultural sector instead of focusing on greater specialization, greater productivity, and institutional reform. The consequences of this decision were probably as harmful as those of the various campaigns described by Professor Nove, and may well have been more lasting. These campaigns, of course, were very significant.

The main problem faced by Brezhnev and his colleagues after Khrushchev's removal was basically similar to that faced by Khrushchev after the death of Stalin. In one sense, the task was easier because of certain Khrushchevian successes and in part also because Nikita Sergeevich's mistakes must have been of some educational value to his successors. The goal was (and still is) to improve efficiency of agricultural production in order to satisfy the population's steadily growing demand for a better and more varied diet. On the other hand, the emergence of certain manpower problems meant that Brezhnev's policy had to be more rational and flexible than was the case until 1964.

Brezhnev's approach to the task of decompressing the command economy in agriculture appeared to be more rational and promising than Khrushchev's. Primacy of local expertise was acknowledged, the practice of escalating grain and other procurement targets ceased, and substantial improvement took place on the level (and in some cases the structure) of Soviet farm prices and in taxes paid by farms. As the Eighth Five-Year Plan is drawing to a close, Brezhnev may justifiably point to a number of achievements in the level of agricultural production and in the efficiency of farming. Perhaps the most important of these gains were reflected in the increase in crop yields. This is due not only to greater availability of fertilizers but also to the absence of major campaigns and to somewhat greater farm autonomy in decision-making and internal affairs. Since 1963 the total Soviet sown area declined from 218.5 to 207 million hectares. The area of clean fallow, reduced drastically in the last Khrushchevian campaign, rose from 6.3 million hectares in 1963 to 18.2 million in 1968. As Professor Nove observes, a noticeable improvement also occurred in milk yields per cow, though it was not until 1967 that milk yields in the public sector surpassed the level achieved in $1959 .{ }^{3}$ On the whole, Brezhnev's policy created a more solid base for future progress than was the case in Khrushchev's early years.

But is all this enough at this stage of Soviet economic development? Lukinov confirms what is only too well known: "the steadily growing demand for food and agricultural raw materials requires the utmost stimulation of the growth of output."4 Indeed, food products (including sales on the collective

3. Nar. khoz., 1964, p. 267, and Nar. khoz., 1968, pp. 334, 408.

4. I. Lukinov, "Tseny i planovo-ekonomicheskoe regulirovanie sel'skokhoziaistvennogo proizvodstva," Voprosy ekonomiki, 1969, no. 1, p. 36. 
farm market) still account for 60 percent of total Soviet retail sales. ${ }^{5}$ Thus the pressures for greater farm output and for greater efficiency of resources employed in agriculture continue unabated.

As these words are written there are numerous indications of considerable strains and stresses in the Soviet economy, and it is possible that a major policy shift is about to take place. At the December 1969 plenum meeting of the Central Committee Brezhnev is said to have criticized bitterly the performance of many sectors of the economy in an as yet unpublished speech. There followed a prolonged campaign of criticism in the daily press. More recently, references are frequently made to a letter-also unpublished-of the Central Committee of CPSU, the Council of Ministers of the USSR, and the central committees of the Komsomol and the trade unions. This letter has the revealing title "On the Improvement of the Utilization of Means of Production and the Increase in the Policy of Economizing in the National Economy." Roughly two weeks before the anniversary of Lenin's birthday the Ukrainian Central Committee devoted a plenary session to a massive critique of livestock production in this important republic, while some time earlier the USSR made fresh commitments for the purchase of meat in New Zealand and Australia. Inflationary pressures continue and are aggravated by the unsatisfactory performance of construction: the volume of unfinished projects relative to annual investments is on the rise again. ${ }^{6}$

Once again the Soviet leadership finds itself facing a familiar problem as its goals and policies impose excessive strain on the available resources. Have agricultural performance and Brezhnev's agricultural policy contributed to these tensions? An affirmative answer is in order. It is now certain that the overall target for the volume of farm output under the Eighth Five-Year Plan (the least ambitious in the history of Soviet planning) will not be met. Moreover, although preliminary calculations indicate that the planned increase in per capita consumption of milk and milk products is likely to be met by 1970 , this will not be true of similar increases in the consumption of meat, fish, fruit and grapes, and sugar (in many instances the discrepancy between the planned goals and the anticipated increases is substantial). ${ }^{7}$

One cause of these developments is the failure of the government to meet its own goals for agricultural investment (see Professor Nove's article) and to allocate to agriculture enough machinery, other equipment, and building

5. Nar. khoz., 1968 , pp. 609,618 .

6. Ibid., p. 529. See also Christian Science Monitor, Apr. 13, 14, 15, 16, 1969, and New York Times, Apr. 5, 1969, sec. 4, p. 2.

7. Pravda, Apr. 10, 1966, and the speech by Gosplan chairman N. K. Baibakov, Pravda, Dec. 17, 1969. The planned increase in the consumption of grapes and fruit was to be 45 to 50 percent, while the corresponding range for meat and meat products was 20 to 25 percent. According to Baibakov, the expected increase for fruit and grapes will come to 18 percent and that for meat and meat products to 15 percent. 
materials. Failure to provide these items cuts several ways. In Soviet climatic conditions the need to perform main farm operations on time is especially great. These days this can only be done if enough machinery in good working order is available on farms. Supplies of machinery which are insufficient to assure the appropriate retirement of old items reduce the productivity of the available machine inventories and raise the rate of utilization (and thus reduce the lifetime) of such machinery as is in working condition. The already high costs of repair and maintenance are raised still further (while depreciation charges continue on dilapidated but not scrapped machinery). This is important, since many Soviet machines are very costly to maintain anyway (there are two hundred lubricating points on the widely used combine SK-4, and fifty-five of them must be lubricated daily ${ }^{8}$ ). The rapid wearing out of machinery is also likely to create problems of bunched investment in the future: it is in fact possible that some of the current Soviet difficulties with machinery supplies reflect a large replacement demand due to the reduction in machinery supplies after 1957. The number of tractors supplied to agriculture was roughly equal to annual replacement requirements only in 1968-69, and no great improvement is planned for 1970 . The situation with other machines is not much better and may be worse in some instances. ${ }^{9}$

The machines that are produced are frequently described as unsuitable or uneconomical to use. About a year ago the deputy director of Soiuzsel'khoztekhnika stated that 1,230 types of farm machines should be produced in the Soviet Union, but that Soviet industry produced only 673 types in 1969. Of these, 282 types were either obsolete or characterized as machines of low productivity. This was also true of a relatively new tractor, DT-75 (fast traction) : many of its parts and subassemblies were said to wear out very rapidly indeed. ${ }^{10}$ Furthermore, the composition of Soviet machinery inventories (and of the agricultural capital stock in general) is far from satisfactory, and this tends to reduce overall productivity of farm capital. In spite of planned increases in capacity to produce machinery, the combined impact of all these factors suggests that the requirements of Soviet farms in machinery

8. V. Shvydko, "Kompleksnaia mekhanizatsiia i elektrifikatsiia-vazhneishii put' povysheniia proizvoditel'nosti truda v sel'skom khoziaistve," Ekonomika sel'skogo khoziaistva, 1969, no. 2, p. 46. According to P. S. Loza, Vosproizvodstvo $i$ ispol'zovanie osnovnykh fondov $v$ kolkhozakh (Moscow, 1969), p. 126, 81 percent of all grain combines in the RSFSR were of the SK-4 type.

9. I. Karliuk, "Tekhnicheskii progress i ukreplenie material'notekhnicheskoi bazy sel'skogo khoziaistva," Voprosy ekonomiki, 1969, no. 12, p. 63. According to Shvydko, "Kompleksnaia mekhanizatsiia $\mathrm{i}$ elektrifikatsiia," p. 49, plows were scrapped at the rate of 28 percent in Estonia and 22 percent in Kazakhstan in 1967. The corresponding figures for combines used for silage crops were 31 and 21 percent. See also Nar. khos., 1968, pp. 417-18, 422.

10. Shvydko, "Kompleksnaia mekhanizatsiia i elektrifikatsiia," p. 43, and Loza, Vosproizvodstvo, p. 122. 
are not likely to be adequately met by Soviet industry for some time to come.

As Professor Nove observes, failure to supply machinery or building materials provides a powerful incentive for the collective farms to increase their payments to labor. The alternative, of course, is to deposit the funds in a Gosbank account. These collective farm deposits are in fact frozen and are used to finance bank loans to other sectors of the economy. One consequence of this situation is the rise of farmers' pay, particularly on richer farms. Some of the Uzbek collectives pay their labor at rates exceeding state farm wages by more than 100 percent. Such practices, as well as payment of salaries to farm chairmen at rates ranging from 515 to 582 rubles per month, are viewed with considerable disapproval by Soviet economists (though I, for one, fail to see why a farm chairman should not be paid at about the same rate as a university professor). "Excessive" distributions to farmers were a major cause for concern at an all-union conference on income distributions in the collective farms (May 1969). Some speakers deplored the fact that more than one-fifth of all collectives made no provision for new investment in 1967 (the corresponding figure for 1968 was four thousand farms or more than 10 percent).$^{11}$

The reasons for this concern are clear: investment usually results in greater labor productivity, and the need for increases in productivity is urgently felt on most farms, but particularly on the collectives affected by labor shortages. In addition, rapid increases in farm wages contribute to inflationary pressures. As the demand for consumer goods increases, so does the need for greater investment to produce these goods. But this also increases competition for investable resources that might be used either directly in agriculture or to produce inputs for agriculture. (International tension is only partly responsible for the failure to fulfill targets for agricultural investment under the current Five-Year Plan. A fuller explanation must take into account competition from other sectors of the economy as well as the continuing waste resulting from the steadily increasing volume of unfinished investment projects.)

But official concern with "inappropriate" distribution of collective farm wages is likely to lead to greater interference with farm autonomy in income distribution and decision-making in general. An increase in the degree of this autonomy was one of the more promising features of the New Agricultural Program of 1965. At the May 1969 conference referred to above, an official of the Tadzhik Ministry of Agriculture declared that steps had already been taken in the majority of Tadzhik collectives to make sure that wages rise only in step with changes in productivity. ${ }^{12} \mathrm{He}$ did not specify the nature of those

11. V. Zhurikov, "Luchshe ispol'zovat' mery material'nogo pooshchreniia kolkhoznikov," Ekonomika sel'skogo khoziaistva, 1969, no. 1, p. 8, and an account of the proceedings of the May 1969 conference in Ekonomika sel'skogo khoziaistva, 1969, no. 9, p. 121.

12. Ekonomika sel'skogo khosiaistva, 1969, no. 9, p. 122. 
steps. In the past, the stress and strain that resulted from conflicts of interest between the farms and the state did, of course, lead to increased party and government interference in the affairs of collective or state farms. At any rate, the ways in which the local government or party agencies may influence production or planning decision of the farms are numerous as well as effective. They may, for example, take the form of binding recommendations to value grain distributions (or sales) to collective farmers at high retail prices, or that of approving or disapproving a particular cropping pattern. But more direct forms of interference may well be forthcoming: on March 24, 1970, G. I. Voronov reportedly threatened farm managers as well as ordinary farmers with sanctions unless their performance improves. ${ }^{13}$

The poor performance of the livestock sector is chiefly due to low yields of feed crops, which can again be traced to lack of proper machinery and fertilizers as well as to earlier neglect. According to calculations for the RSFSR (which accounts for more than one-half of the total Soviet output of livestock products) the deficit of feed on all farms exceeds 25 percent, and the deficit of protein in animal rations comes to 2.4 million tons or 20 percent of requirements. ${ }^{14}$ Yields of annual and perennial grasses are said to have declined recently, while those of other feed crops did not increase. In the years 1965, 1966, and 1967 the increase in the supply of all feed per head of all livestock was less than 2 percent (significantly, perhaps, no data were published for 1968). In many areas bare subsistence rations are fed to animals during the winter, a factor that can only compound the difficulties related to the feed problem. ${ }^{15}$ Under the circumstances, the rise in livestock herds that occurred in 1966-67 must have been premature. Only the high level of (and the rapid growth in) the demand for livestock products can explain the expansion of animal husbandry and procurement of livestock products in such high cost areas as Transcaucasia and Central Asia. ${ }^{16}$

All in all, the progress in specialization since 1965 must still be viewed as disappointing. In 1967, grain was produced on 97.8 percent of all collectives, while the corresponding figures for milk and pork were 99.8 and 81.9 percent respectively. ${ }^{17}$ This state of affairs must be due largely to the administrative procedures used in setting the procurement quotas. Ironically, however, one

13. Zhurikov, "Luchshe ispol'zovat' mery material'nogo pooshchreniia kolkhoznikov," p. 10; Voronov's speech was published in Leninskaia znamia, Mar. 24, 1970. I quote from a report by Paul Wohl in Christian Science Monitor, Apr. 14, 1970.

14. M. Smugiryn, "Rezervy snizheniia sebestoimosti kormov," Ekonomika sel'skogo khoziaistva, 1969, no. 9, p. 57, and L. Florentiev, "Puti povysheniia proizvoditel'nosti truda i snizheniia sebestoimosti," ibid., p. 48.

15. Nar. khoz., 1968, p. 411, and A. Kosynkin, "Glavnoe uslovie dal'neishego pod"'ema ekonomiki khoziaistv," Ekonomika sel'skogo khoziaistva, 1969, no. 3, p. 22.

16. F. Savitsky, "Povyshat' ekonomicheskuiu effektivnost' proizvodstva," Ekonomika. sel'skogo khoziaistva, 1969, no. 9, p. 6.

17. Ekonomika sel'skogo khoziaistva, 1969, no. 3, p. 124. 
of the otherwise progressive measures of the New Agricultural Program may also contribute to delays in the introduction of further specialization: procurement plans received in 1965 (when there was little specialization) remained unalterable-at least in theory-for the duration of the Eighth Five-Year Plan. It is problematic whether much improvement can be expected in the plan being drafted for 1971-75, unless the rules of the game are changed. According to tecisions of the October 1968 plenum, unalterable procurement plans (which determine the structure of production quite effectively in Soviet conditions) were to be approved by March 1, 1969. Four months was hardly long enough to "work out perspective specialization for each collective and state farm."18

If plans for the supply of inputs to agriculture will not be met, targets to raise the income of collective farmers certainly will (state farm wages also have risen appreciably since 1965). These increases, which clearly contributed to the inflationary pressures, were nevertheless deemed necessary not so much on grounds of equity but because of another dilemma that faces the Soviet leadership at this time in the field of labor supply. Because of very pronounced regional differences, national data are not very helpful in this context: since 1959 the rural population has declined by 4 million, though its numbers have increased in nine union republics. (In the Uzbek republic alone the increase came to nearly 2 million persons, or 36 percent.) All republics in Central Asia and the Transcaucasus fall into this category. By contrast, rural population in the RSFSR declined by 7.1 million between January 1959 and January 1, 1969.19 According to Dr. Karl-Eugen Wädekin, " 25 out of 70 RSFSR oblasts were considered to have an absolute deficit of agricultural labour [in 1965], and almost half of the agricultural area of the RSFSR was located in just these oblasts."20

Two years ago Wädekin argued that the success of the New Agricultural Program in (temporarily) arresting the outflow of labor from the village was the decisive factor in the overall agricultural improvement in 1966-67. ${ }^{21}$ Since then a Soviet economist has also argued that trends in agricultural manpower have been of major importance for the success of various agricultural policies in the past. It is, of course, expected that the agricultural labor force will decline both absolutely and relatively as the economy continues to grow. But this is only an indication of the general direction of a trend that calls for a large supply of capital and other inputs to agriculture. To paraphrase Wädekin, the Soviet farm labor problem is closely related to the rate and the regional structure of rural outmigration, as well as to the present age, sex, and pro-

18. A. M. Emelianov, "Problemy i perspektivy razvitiia sel'skogo khoziaistva v svete reshenii oktiabrskogo (1968) Plenuma TsK KPSS," Vestnik Moskovskogo universiteta, ser. 8, no. 2 (1969), p. 9.

19. Nar. khoz., 1968, pp. 10-11.

20. Karl-Eugen Wädekin, "Manpower in Soviet Agriculture-Some Post-Khrushchev Developments and Problems," Soviet Studies, 20, no. 3 (January 1969) : 290.

21. Ibid., p. 285. 
fessional structure of the agricultural labor force. Farm labor available in large numbers in Azerbaijan and in the Central Asian republics is not likely to be very mobile on ethnic, cultural, and other grounds. Moreover, the age structure of present agricultural manpower is such that a reduction in the farm labor force could have been expected in the absence of migration to urban areas. The present average age in farming is about fifty, and the share of ablebodied individuals in the declining rural population of the RSFSR dropped from 54 percent in 1959 to 47 percent in $1967 .{ }^{22}$ It is improbable that retention of the overage groups (by one means or another) in the labor force can provide a satisfactory way out. ${ }^{23}$

All over the world young people leave agriculture, but the Soviet case is indeed special, especially since the demand of farms for various capital items and other off-farm inputs is not satisfied. As things stand now, only 17 percent of rural youngsters who continue their education choose agricultural curricula. The primacy of personal interest, lack of incentive to return to the village, and the general unpopularity of agriculture are said to be the main causes for this state of affairs and for the migration of the rural young in general. ${ }^{24}$

In addition, the high rate of turnover among skilled agricultural workers continues. In 1966-68 a total of 1,630,000 "mechanizers" were trained in the USSR, but their number on farms increased by only 263,000 . During the same period, graduates in agricultural studies from institutions of higher and specialized secondary education numbered 457,000 , but the number of all graduates of such institutions employed on farms rose only by $95 ; 000 .{ }^{25}$ Soviet sources quoted by Wädekin indicate that by 1970 the demand for all "mechanizers" (including truck drivers) would amount to 10 million; the corresponding figure for specialists is 2 million (including 630,000 university graduates). The number of "mechanizers" employed on farms in 1968 was 3.4 million, and that of specialists 671,000 (including 180,000 university graduates). ${ }^{26}$

As we have seen, the supply of capital goods to agriculture has fallen behind schedule, and trends in agricultural manpower are very discouraging. In 1970, therefore, the Brezhnev regime finds itself in a particularly difficult situation: it must supply enough capital goods and other off-farm inputs to replace retiring and migrating labor. At this stage of development, the solution of the Soviet farm problem no longer depends on agriculture but rather on

22. L. Bulochnikova, "Sel'skaia migratsiia i puti ego regulirovaniia," Planovoe khoziaistvo, 1969, no. 8, pp. 73, 74. The agricultural labor force, measured in terms of average number employed, rose by 2.3 million from 1953 to 1958 . It then declined by 2.1 million during the period of sluggish growth in 1959-64.

23. Wädekin, "Manpower in Soviet Agriculture," pp. 291-92.

24. Bulochnikova, "Sel'skaia migratsiia," p. 72.

25. Nar. khoz., 1968 , pp. $448,454,565,691$.

26. Wädekin, "Manpower in Soviet Agriculture," pp. 293-94, and Nar. khos., 1968, pp. $448,454$. 
improvement in industrial performance. It calls for a degree of efficiency and skill in coordinating production and supplies of various complementary inputs that is unheard of in Soviet conditions.

The "reformed" Soviet industry is clearly unable to accomplish this task in the near future. Large shifts of resources to a given sector are usually achieved effectively, within such a short period of time, by means of command rather than market instruments of policy. The reported disenchantment with the industrial reform and desire to return to greater centralization in planning and management are thus easily understandable. This tendency is further strengthened by the dead hand of the Soviet past. But if past experience is any guide, the return to greater use of command instruments for coordinating economic activity will decrease rather than increase efficiency in the industrial sector as well as in distribution. The benefits that might be gained from a rapid shift of resources may well turn out to be disproportionately small in relation to costs. The solution clearly lies in the direction of further and bolder reform and in the redirection of national priorities. The present collective leadership is unlikely to proceed in this manner: a steady hand at the helm and a sense of well-defined purpose are required. A temporary remedy might thus well be sought in partial recentralization.

The government must also make sure that there is enough labor in the important farm areas to operate the new capital goods efficiently. Here, too, a palliative might be sought in restrictions on freedom to move (this was done in the case of specialists under Khrushchev) and perhaps even by direction of labor. Serious local shortages of manpower may be one of the reasons why the new Model Charter for Collectives did not grant to the collective farmers an outright freedom to move. In the past, restrictions on the mobility of agricultural labor proved singularly ineffective. A wider application of the Shchedrino experiment could alter the situation, but such changes depend upon the continuation of the reform, and the wrong kind of recentralization could prove fatal in this respect as well. Restrictions on freedom to move are not likely to result in a substantial improvement of the productivity of agricultural labor in any case.

In order to be really effective, the greater supply of complementary capital goods and other off-farm inputs must be accompanied by a still greater autonomy of local decision-making. Benefits to be derived from greater flexibility at the farm level depend in turn on the provision of an efficient, truly "marketized" system of supply and agricultural services. This, too, is not likely to be accomplished by centralization and physical allocation of resources.

The last chapters in the treatise on the decompression of the Soviet command economy are still to be written. It remains to be seen whether the considerable improvement in agriculture achieved under Brezhnev will once more prove to be a discreet, "one shot" increase in productivity. In the past, such 
improvements were followed by periods of sluggish growth. The renewed emphasis on the potential contribution of the private sector (where some restrictions appear to have been introduced by lower government agencies in the recent past ${ }^{27}$ ) can be interpreted as evidence of some apprehension of such prospects among the top leadership. This, then, is a distinct possibility for the near future. The long-run outlook is obviously much better, because the "Green Revolution" in agricultural productivity has not yet happened in the USSR. In the meantime, it is well to remember that-like Khrushchev in the past-Brezhnev is forced to pay heavy installments on the debt incurred by Stalin in the late twenties and compounded by the subsequent pattern of Soviet industrialization. The amount of interest paid by successive generations of Soviet consumers is staggering indeed, and a considerable part of it remains to be paid in the future.

The comments above were written before the July plenum. It is comforting that my views are shared by one so well informed about the state of agriculture as Brezhnev must be. Forty-one years after collectivization, "any and all increase in grain output remains, as earlier, the central problem." ${ }^{28}$ A new version of the New Agricultural Program is about to be implemented: prices are increased; state investment in agriculture will be 77.6 billion rubles, or 25 percent of total state investment. Fertilizer output is to rise to 90 million tons-or twice the amount of 1968 production. If these goals are fulfilled (and skepticism is in order), some things will improve. But targets for new machinery inputs are disappointing: they are often lower than targets for 1966-70. Tractor deliveries will just about suffice to replace those that should be scrapped, and it remains to be seen if the overhaul of the machinery supply and repair establishment will amount to an improvement. Brezhnev was silent on issues of autonomy and flexibility: he did stress party leadership, discipline, and the "first commandment," referring, as did Stalin, to deliveries to the state. The resurrected state inspectorates for procurements are likely to reduce management autonomy. That the Party Congress was postponed till March 1971 may well reflect continuing struggle about "what is to be done" to get Soviet farming going in a really meaningful sense.

27. For example, the complaints about restrictions made at the session of the Latvian Central Committee and reported in Pravda, Jan. 21, 1970. 1970.

28. Sel'skaia zhizn', July 3, 1970. See also ibid., July 4, 18, 19, 21, and 25 and Aug. 7, 